Prosiding Seminar Nasional Teknologi Informasi dan Kedirgantaraan : Transformasi Teknologi untuk Mendukung Ketahanan Nasional, Yogyakarta, 13 Desember 2018

SENATIK 2018, Vol. IV, ISBN 978-602-52742-0-6

DOI: http://dx.doi.org/10.28989/senatik.v4i0.216

\title{
DECISION SUPPORT SYSTEM TO DETERMINE THE NUMBER OF PRODUCTION TOFU USING THE FUZZY SUGENO METHOD (Case Study: Home Industries Tofu in Seyegan District) Yuliani Indrianingsih
}

Program Studi Informatika

Sekolah Tinggi Teknologi Adisutjipto

Jl. Janti, Blok-R, Lanud Adisucipto Yogyakarta

Email : yulistta@gmail.com

\begin{abstract}
The production process is a way to increase the usefulness of an item and service using existing production factors. The decision making process to determine the amount of production, especially in the business world contains risks. It needs to be supported by careful calculations so that the risk of loss can be avoided. Industri associations tofu "Waluyo" in Seyegan who still determines the amount of production manually. From the above problems a Decision Support System (DSS) was made using Sugeno's fuzzy method. In this DSS there are three variables modeled, namely, inventory variables, demand variables and production variables. The demand variable consists of two fuzzy sets, the inventory variable consists of two fuzzy sets and 4 rules which are the production rules used by Industry associations tofu "Waluyo" in determining the amount of production. Based on the acuracy test using the MAPE (Mean Absolute Percentage Error) method obtained a value of $5,3069 \%$ or below the error rate of 10\%. So this system can be applied in determining the amount of tofu production in the tofu industri community in Seyegan.
\end{abstract}

Keywords : Tofu, DSS, Fuzzy Sugeno Method

Abstrak

Proses produksi adalah suatu cara untuk menambah kegunaan suatu barang dan jasa menggunakan faktor produksi yang ada. Proses pengambilan keputusan untuk menentukan jumlah produksi, terutama dalam dunia usaha mengandung resiko. Perlu didukung perhitungan yang matang agar resiko kerugian dapat dihindari. Paguyuban industri tahu "Waluyo" di Seyegan masih menentukan jumlah produksi secara manual. Dari permasalahan diatas dibuat suatu sistem pendukung keputusan (SPK) menggunakan metode fuzzy Sugeno. Dalam SPK ini terdapat tiga variabel yang dimodelkan yaitu, variabel persediaan, variabel permintaan dan variabel produksi. Variabel permintaan terdiri atas dua himpunan fuzzy, variabel persediaan terdiri atas dua himpunan fuzzy dan 4 rule yang merupakan aturan produksi yang digunakan oleh paguyuban tahu dalam menentukan jumlah produksi.Berdasarkan uji akurasi menggunakan metode MAPE (Mean Absolute Percentage Error) diperoleh nilai MAPE sebesar 5,3069 \% atau dibawah tingkat kesalahan 10\% . Jadi metode fuzzy sugeno dapat diterapkan dalam penentuan jumlah produksi tahu pada Paguyuban industri tahu di Seyegan.

Kata kunci: Tahu, SPK, metode Fuzzy Sugeno

\section{Pendahuluan}

Sistem Pendukung Keputusan merupakan suatu sistem yang interaktif, yang membantu pengambilan keputusan melalui penggunaan data dan model-model keputusan untuk memecahkan masalah yang sifatnya semi terstruktur maupun yang tidak terstruktur. Penyelesaian masalah yang dilakukan dengan menentukan alternatif-alternatif solusi. 
Tahu merupakan produk makanan berbahan baku kedelai yang sudah dikenal sejak lama di Indonesia. Berbeda dengan tempe yang merupakan makanan asli Indonesia, tahu merupakan produk makanan asal China [1]. Sebagaimana produk tempe, tahu juga banyak digemari oleh masyarakat Indonesia karena memiliki cita rasa yang nikmat, bergizi tinggi dan harganya juga terjangkau. Di Indonesia, tahu sudah menjadi makanan yang sangat familier dikonsumsi oleh masyaratkat kelas bawah maupun kelas atas. Tahu sudah menjadi masakan yang sangat familier banyak dijumpai di warung-warung sekelas warteg hingga restoran papan atas. Hal ini menunjukan bahwa tahu memiliki pangsa pasar yang luas [1]. Tahu merupakan produk makanan yang mudah rusak karena memiliki kadar air dan protein tinggi merupakan media tumbuh yang potensial bagi mikroorganisme pembusuk. Produk tahu memiliki umur simpan yang singkat 2-3 hari, hal ini menjadi faktor kendala untuk mencapai pasar yang lebih luas. Umumnya para pengrajin tahu berproduksi dalam skala home industri dengan kapasitas produksi sesuai kemampuan memasarkan hasil produksinya [2].

Selama ini perajin tahu belum memiliki aplikasi dalam mengambil keputusan untuk menentukan jumlah produksi tahu setiap harinya. Pengambilan keputusan yang dilakukan secara manual dengan standarisasi penentuan yang telah ditentukan oleh Paguyuban. Dari masalah penentuan jumlah produksi tahu tersebut, dapat menggunakan logika fuzzy. Metode yang digunakan dalam pengaplikasian logika fuzzy pada produksi tahu adalah metode fuzzy sugeno. Penalaran metode Sugeno menghasilkan output sistem berupa konstanta atau persamaan linear. Produksi sebuah perusahaan bergantung pada variable-variabelnya, misalkan : persediaan, permintaan dan lain-lain[3]. Pada prakteknya, variabel-variabel tersebut tidak dapat diketahui secara pasti. Bila terjadi hal ini salah satu solusinya dapat dicari dengan menggunakan operasi himpunan fuzzy. Alasan digunakan metode sugeno karena memiliki toleransi terhadap data-data yang tidak tepat [4]. Sesuai latar belakang, penelitian ini dirancang untuk menentukan jumlah produksi tahu di desa Krapyak Kecamatan Seyegan. Diharapkan dengan sistem ini dapat dijadikan alat bantu dalam mengambil keputusan untuk menentukan jumlah produksi tahu di desa Krapyak Seyegan Sleman.

\section{Metode Penelitian}

Dalam menentukan jumlah produksi tahu ada 3 variabel fuzzy yaitu variabel yang akan dibahas dalam sistem ini. Variabel fuzzy tersebut sebagai berikut:

a.Persediaan

Variabel persediaan adalah variabel input-an yang akan di-input dalam aplikasi ini.

b.Permintaan

Variabel permintaan adalah variabel input-an yang akan di-input dalam aplikasi ini.

c.Produksi

Variabel produksi adalah variabel output yang merupakan variabel yang dihasilkan dari proses yang dilakukan dalam sistem ini.

\section{Gambaran Umum Sistem}

Penggunaan sistem ini adalah admin dan user. Dimana user akan menginputkan unsur-unsur yang akan diujikan dan sistem akan mengolah data masukan tersebut, sehingga output berupa hasil perhitungan jumlah produksi tahu. Pengguna sebagai admin dapat melakukan proses tambah, ubah dan hapus data (manipulasi data). 


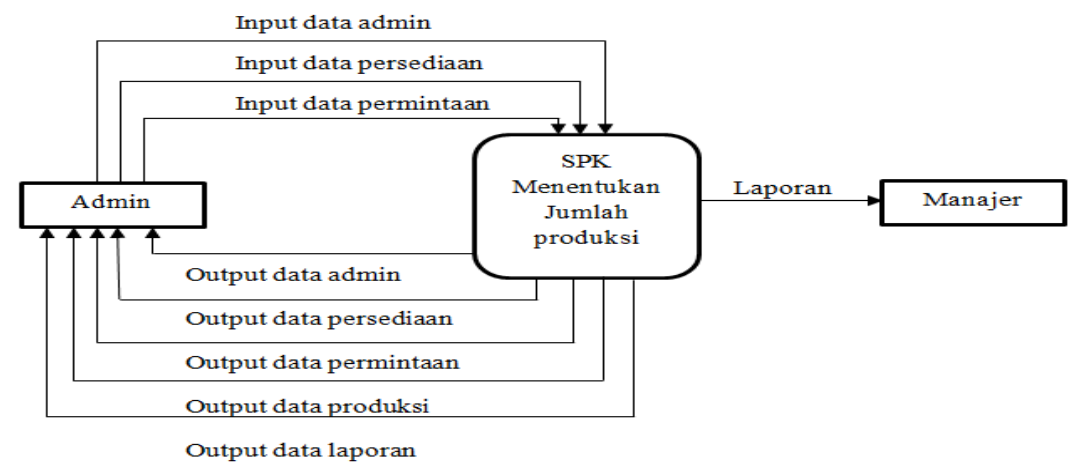

Gambar 3 Diagram konteks

Penelitian terdahulu yang sudah dilakukan oleh peneliti lain terkait dengan produksi, persediaan dan permintaan menggunakan metode logika fuzzy yaitu:

1. Perencanaan strategis dilakukan agar perusahaan dapat melihatnya secara obyektif secara internal dan kondisi eksternal yang memungkinkan perusahaan mengantisipasi perubahan di lingkungan eksternal untuk menentukan perusahaan mana yang akan menghasilkan gambaran dari internal dan eksternal lingkungan Hidup. Selanjutnya melakukan analisis untuk merumuskan strategi yang tepat alternatif untuk memposisikan perusahaan. Tahap terakhir adalah strategi pengambilan keputusan menggunakan metode yang ada [7].

2. Program swasembada pemerintah tentang Sapi dan Kerbau belum berhasil, karena distribusi ternak tidak sesuai dengan peraturan. Ini hanya digunakan faktor ekologis dan belum menggunakan faktor lain seperti sumber daya manusia dan kelembagaan faktor, teknologi dan pengembangan faktor wilayah, pengembangan infrastruktur. Penelitian ini telah dilakukan pemodelan dengan Multi Kriteria Decision Making (MCDM). Simple Additive Weighting (SAW) adalah salah satu metode MCDM, yang digunakan untuk menentukan kesesuaian lokasi ternak telah berjalan dengan baik [8].

3. PT Madu Baru Yogyakarta adalah perusahaan yang memproduksi gula. Banyak faktor harus dipertimbangkan dalam menentukan tingkat produksi yang dihasilkan setiap tahun. Untuk itu, dalam menentukan jumlah produksi pertahun dan analisis perlu sistem dukungan keputusan dan analisis sistem akan dilakukan dengan menerapkan Metode Fuzzy Inference System Tsukamoto, Metode Inferensi Sistem Mamdani menggunakan min sebagai fungsi implikasinya, dari masing-masing aturan memberikan tingkat keanggotaan terkecil (defuzzifikasi), kedua metode tersebut dibandingkan, untuk memperoleh jumlah produksi gula yang maksimal, Penerapan sistem inferensi fuzzy Tsukamoto akan dibandingkan dengan penghematan yang disarankan akan diterapkan ke sistem. Aplikasi fuzzy Tsukamoto dan Mamdani memberikan gambaran tentang perbedaan yang menentukan hasil akhir dari proses defuzzifikasi, sehingga metode yang dikenal cocok untuk merekomendasikan nilai simpanan dengan output terbatas dari nilai-nilai tertentu (batas bawah dan atas deposito). Perhitungan Fuzzy telah diuji dengan analisis perhitungan matematis secara manual dan menghasilkan nilai yang sama [9] [10].

4. Penelitian yang bertujuan untuk memperbaiki produktivitas lahan, agar lahan dapat ditanami jenis palawija yang tepat berdasar kandungan zat lahan itu. Banyaknya masyarakat petani yang masih menggunakan pembelajaran secara otodidak dan pengalaman secara turun temurun dalam penentuan jenis tanaman palawija yang ditanam mereka, menyebabkan hasil panen yang tidak maksimal. Sehingga dibutuhkan sebuah Sistem Pendukung Keputusan (SPK) yang dapat membantu para petani untuk menentukan jenis tanaman palawija untuk meningkatkan produktivitas lahan [11].

5. Teknologi informasi dibutuhkan dan dapat diterapkan sebagai suatu keputusan mendukung kegiatan manajerial alat di kampus. Penelitian ini bertujuan untuk mengembangkan keputusan sistem pendukung untuk Sekolah Tinggi Teknologi Adisutjipto (STTA), yaitu 
penerimaan siswa baru, terutama jalur pencapaian, menggunakan Simple Multi Atribut Rating Teknik berbasis Web, di mana dalam metode ini memilih kriteria alternatif .

Teknik yang digunakan untuk membuat DSS, satu dengan Fuzzy Logic Multi-Attribute Decision Making (MADM). Logika fuzzy adalah satu masalah pada perasaan. Dimana derajat keanggotaan biasanya diwakili dengan nilai 0 dan 1, dengan Logika Fuzzy adalah derajat keanggotaan dapat diwakili dengan nilai antara 0 dan 1 , yang dapat lebih seimbang. Dalam mewujudkan, kebutuhan akan guru berkualitas baik yang dapat menjadi teladan bagi siswa, sehingga proses belajar mengajar akan menjadi lebih baik. Dengan demikian penilaian kebutuhan dilakukan oleh siswa atau kepala sekolah untuk mengetahui kemampuan baik dalam proses mengajar maupun di luar proses mengajar. Metode yang digunakan logika fuzzy MADM SAW dalam perhitungannya. Diharapkan DSS dapat menjadi alternatif dalam pemilihan guru teladan di SMA Yogyakarta [12][13].

\section{Penentuan Fungsi Keanggotaan}

Fungsi keanggotan yang digunakan dalam menentukan jumlah produksi ini adalah Grafik Bahu Kiri-Bahu kanan. Berikut adalah fungsi keanggotan dalam himpunan fuzzy ini, sebagai berikut :

a.Permintaan (x), terdiri atas 2 himpunan fuzzy yaitu naik dan turun, seperti gambar berikut ini :

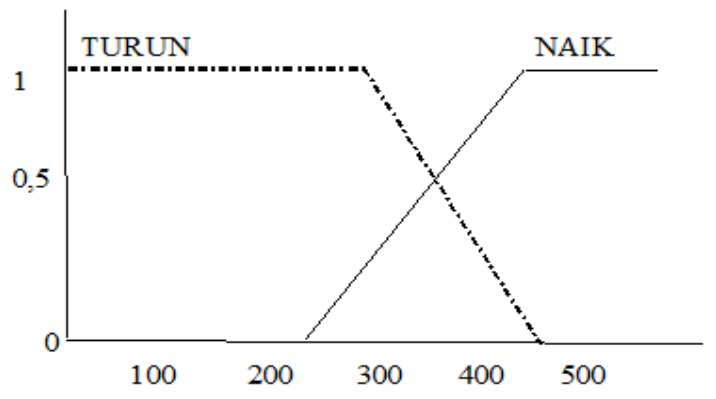

Gambar 4 Variabel Permintaan

Dari Gambar 4 dapat dilihat $220 \mathrm{~kg}$ merupakan jumlah permintaan terendah yang pernah dicapai sedangkan $470 \mathrm{~kg}$ adalah jumlah permintaan terbanyak yang dicapai oleh Paguyuban industri tahu .

b.Persediaan (y), terdiri atas 2 himpunan fuzzy yaitu sedikit dan banyak, seperti gambar berikut ini:

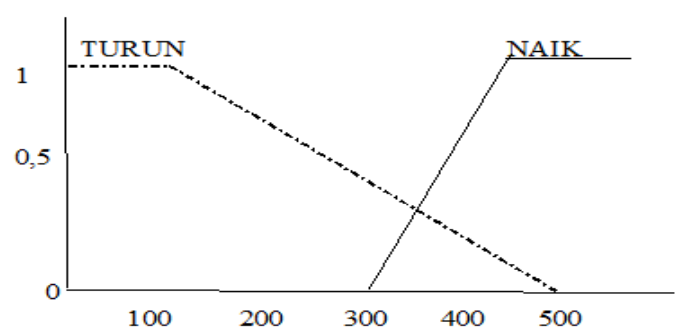

Gambar 5 Variabel Persediaan

Dari gambar 5 dapat dilihat $300 \mathrm{~kg}$ tahu adalah jumlah persediaan paling sedikit dan $500 \mathrm{~kg}$ tahu adalah persediaan yang paling banyak yang ada pada paguyuban industri tahu "Waluyo". 


\section{Pembentukan Rule}

Terdapat 4 rule untuk menentukan jumlah produksi tahu, rule ini didapat dari paguyuban merupakan aturan yang digunakan dalam home industri tersebut. Rule yang digunakan sebagai berikut :

[R1] IF Permintaan TURUN AND Persediaan BANYAK THEN Produksi $=2 *$ Permintaan 400;

[R2] IF Permintaan TURUN AND Persediaan SEDIKIT THEN Produksi = Permintaan;

[R3] IF Permintaan NAIK AND Persediaan BANYAK THEN Produksi = Permintaan;

[R4] IF Permintaan NAIK AND Persediaan SEDIKIT THEN Produksi $=0,25 *$ Permintaan + 100 ;

Untuk melihat tabel data produksi tahu bulan September 2018 dapat dilihat pada tabel data produksi bulan september, seperti pada tabel 1 .

Tabel 1 Tabel Data Produksi Tahu Bulan September Tahun 2018

(Sumber: Paguyuban Indusri Tahu "Waluyo")

\begin{tabular}{|c|c|c|c|}
\hline Tanggal & Permintaan & Persediaan & Produksi \\
\hline 01-September & 230 & 300 & 230 \\
\hline 02-September & 280 & 400 & 285 \\
\hline 03-September & 340 & 350 & 340 \\
\hline 04-September & 410 & 500 & 410 \\
\hline 05-September & 350 & 450 & 350 \\
\hline 06-September & 420 & 400 & 420 \\
\hline 07-September & 280 & 350 & 292 \\
\hline 08-September & 400 & 400 & 410 \\
\hline 09-September & 380 & 350 & 395 \\
\hline 10-September & 280 & 400 & 280 \\
\hline 11-September & 340 & 400 & 350 \\
\hline 12-September & 390 & 400 & 400 \\
\hline 13-September & 220 & 350 & 220 \\
\hline 14-September & 420 & 350 & 420 \\
\hline 15-September & 410 & 400 & 410 \\
\hline 16-September & 250 & 350 & 275 \\
\hline 17-September & 360 & 400 & 372 \\
\hline 18-September & 380 & 500 & 394 \\
\hline 19-September & 290 & 300 & 300 \\
\hline 20-September & 410 & 500 & 410 \\
\hline 21-September & 440 & 450 & 470 \\
\hline 22-September & 378 & 450 & 378 \\
\hline 23-September & 420 & 500 & 428 \\
\hline 24-September & 220 & 300 & 220 \\
\hline 25-September & 280 & 400 & 280 \\
\hline 26-September & 320 & 350 & 320 \\
\hline 27-September & 390 & 500 & 398 \\
\hline 28-September & 270 & 300 & 270 \\
\hline 29-September & 380 & 400 & 380 \\
\hline 30-September & 420 & 450 & 420 \\
\hline
\end{tabular}

Dari data bulan September 2018, permintaan terbesar mencapai $440 \mathrm{~kg}$ tahu per hari, dan permintaan terkecil mencapai $220 \mathrm{~kg}$ tahu per hari. Persediaan tahu terbanyak mencapai $500 \mathrm{~kg}$ dan persediaan terkecil mencapai $300 \mathrm{~kg}$. Dari data yang ada saat ini paguyuban 
industri tahu "Waluyo" memproduksi paling banyak $500 \mathrm{~kg}$ tahu dan paling sedikit $300 \mathrm{~kg}$ tahu.

\section{Hasil Dan Pembahasan}

Tabel 1 adalah tabel data dari Paguyuban terkait jumlah produksi tahu pada bulan September 2018 yang akan dibandingkan antara hasil perhitungan manual dengan perhitungan menggunakan metode fuzzy sugeno.

\section{Gambaran Penentuan Jumlah Produksi}

Produksi tahu untuk tanggal 21 September 2018, jumlah permintaan sebesar $440 \mathrm{~kg}$ tahu dan jumlah persediaan yang $450 \mathrm{~kg}$. Menghitung jumlah yang akan diproduksi berdasarkan metode fuzzy sugeno, sebagai berikut:

Jika diketahui permintaan pada tanggal 21 September 2018 sebesar $440 \mathrm{~kg}$, maka :

Tahap ke-1 : Fuzzyfikasi

a. Permintaan (x) (Pmt), terdiri atas 2 himpunan fuzzy, yaitu SEDIKIT dan BANYAK, menggunakan fungsi keanggotaan bahu kanan-bahu kiri seperti tercantum pada gambar 4 , dapat dirumuskan :

$$
\begin{aligned}
\mu \operatorname{Pmt}_{\text {TURUN }}(\mathrm{x}) & = \begin{cases}1 & ; \mathrm{x}<220 \\
\frac{470-x}{470-220} & ; 220 \leq \mathrm{x} \leq 470\end{cases} \\
\mu \operatorname{Pmt}_{\text {NAIK }}(\mathrm{x}) & = \begin{cases}0 & ; \mathrm{x}>470 \\
0 & ; \mathrm{x}<220 \\
\frac{x-220}{470-220} & ; 22 \leq \mathrm{x} \leq 470 \\
1 & ; \mathrm{x}>470\end{cases}
\end{aligned}
$$

Maka dapat dihitung untuk nilai permintaan yaitu:

$$
\begin{array}{ll}
\mu \text { Pmt }_{\text {TURUN }}(440)=\frac{470-x}{470-220} & =\frac{470-440}{470-220}=0,12 \\
\mu \text { Pmt }_{\text {NAIK }}(440)=\frac{x-220}{470-220} & =\frac{440-220}{470-220}=0,88
\end{array}
$$

b. Persediaan (y) (Psd), terdiri atas 2 himpunan fuzzy, yaitu SEDIKIT dan BANYAK, menggunakan fungsi keanggotaan bahu kanan-bahu kiri seperti yang tercantum gambar 5 diatas, dapat dirumuskan :

$$
\begin{aligned}
\mu \operatorname{Psd}_{\text {SEDIKIT }}(\mathrm{y}) & =\left\{\begin{array}{cl}
1 & ; \mathrm{x}<300 \\
\frac{500-y}{500-300} & ; 300 \leq \mathrm{x} \leq 500 \\
0 & ; \mathrm{x}>500
\end{array}\right. \\
\mu \operatorname{Psd}_{\text {BANYAK }}(\mathrm{y}) & = \begin{cases}0 & ; \mathrm{x}<300 \\
\frac{y-300}{500-300} & ; 300 \leq \mathrm{x} \leq 500 \\
1 & ; \mathrm{x}>500\end{cases}
\end{aligned}
$$

Maka dapat dihitung nilai persediaan pada tanggal 21 September 2018 sebesar $450 \mathrm{~kg}$, maka : 


$$
\begin{array}{ll}
\mu \operatorname{Psd}_{\text {SEDIKIT }}(450)=\frac{500-y}{500-300} & =\frac{500-450}{200}=0,25 \\
\mu \operatorname{Psd}_{\text {BANYAK }}(450)=\frac{y-300}{500-300} & =\frac{450-300}{200}=0,75
\end{array}
$$

Selanjutnya menghitung Produksi (Z), yaitu:

\section{Tahap ke-2 : Pembentukan Rule}

[R1] IF Permintaan TURUN AND Persediaan BANYAK THEN Produksi $=2 *$ Permintaan 400;

[R2] IF Permintaan TURUN AND Persediaan SEDIKIT THEN Produksi = Permintaan;

[R3] IF Permintaan NAIK AND Persediaan BANYAK THEN Produksi = Permintaan;

[R4] IF Permintaan NAIK AND Persediaan SEDIKIT THEN Produksi $=0,25 *$ Permintaan + 100

\section{Tahap ke-3 : Mesin Inferensi}

[R1] IF Permintaan TURUN AND Persediaan BANYAK THEN Produksi $=2 *$ Permintaan -400 ;

$$
\begin{aligned}
& \alpha \text { - } \text { predikat }_{1} \quad=\mu \text { Pmt }_{\text {TURUN }} \cap \mu \operatorname{Psd}_{\text {BANYAK }} \\
& \quad=\min \left(\mu \text { Pmt }_{\mathrm{TURUN}}(440), \mu \operatorname{Psd}_{\text {BANYAK }}(450)\right) \\
& \quad=\min (0,12 ; 0,75)=0,12 \\
& \mathrm{Z}_{1}=(2 \times 440)-450=430
\end{aligned}
$$

[R2] IF Permintaan TURUN AND Persediaan SEDIKIT THEN Produksi = Permintaan;

$$
\begin{aligned}
& \alpha \text {-predikat }{ }_{2} \quad=\mu \text { Pmt }_{\text {TURUN }} \cap \mu \text { Psd }_{\text {SEDIKIT }} \\
& \quad=\min \left(\mu \text { Pmt }_{\text {TURUN }}(440), \mu \text { Psd }_{\text {SEDIKIT }}(450)\right) \\
& \quad=\min (0,12 ; 0,25)=0,12 \\
& \mathrm{Z}_{2}=440
\end{aligned}
$$

[R3] IF Permintaan NAIK AND Persediaan BANYAK THEN Produksi = Permintaan;

$$
\begin{aligned}
& \alpha \text {-predikat }{ }_{3} \quad=\mu \text { Pmt }_{\text {NAIK }} \cap \mu \text { Psd }_{\text {BANYAK }} \\
& \quad=\min \left(\mu \text { Pmt }_{\text {NAIK }}(440), \mu \operatorname{Psd}_{\text {BANYAK }}(450)\right) \\
& \quad=\min (0,88 ; 0,75)=0,88 \\
& Z_{3}=440
\end{aligned}
$$

[R4] IF Permintaan NAIK AND Persediaan SEDIKIT THEN Produksi $=0,25^{*}$ Permintaan $+100$

$$
\begin{aligned}
& \alpha-\text { predikat }_{4}=\mu \text { Pmt }_{\text {NAIK }} \cap \mu \text { Psd }_{\text {SEDIKIT }} \\
& =\min \left(\mu \text { Pmt }_{\text {NAIK }}(440), \mu \text { Psd }_{\text {SEDIKIT }}(450)\right) \\
& =\min (0,88 ; 0,759)=0,75 \\
& \mathrm{Z}_{4}=\left(0,25^{*} 440\right)+100=210
\end{aligned}
$$

\section{Tahap ke-4 : Defuzzyfikasi}

Diperoleh banyaknya tahu yang harus diproduksi tanggal 21 September 2014 :

$$
\begin{aligned}
Z & =\frac{0,75 \times 480+0,12 \times 440+0,75 \times 440+0,88 \times 210}{0,75+0,12+0,75+0,88} \\
& =\frac{360+528+330+184,8}{2,5} \\
& =561,12
\end{aligned}
$$

Dari contoh perhitungan di atas, diperoleh jumlah produksi menggunakan metode Fuzzy Sugeno seperti tercantum pada tabel 2. 
Tabel 2 Tabel Perbandingan Data Produksi Paguyuban dengan Metode Fuzzy Sugeno.

\begin{tabular}{|c|c|c|c|c|c|}
\hline \multirow[t]{2}{*}{ Tanggal } & \multirow{2}{*}{$\begin{array}{c}\text { Permintaan } \\
\text { (per-kg) }\end{array}$} & \multirow{2}{*}{$\begin{array}{c}\text { Persediaan } \\
\text { (per-kg) }\end{array}$} & \multicolumn{2}{|c|}{ Produksi (per-kg) } & \multirow{2}{*}{$\begin{array}{l}\text { Selisih } \\
(A i-B i)\end{array}$} \\
\hline & & & $\begin{array}{c}\text { Paguyuban } \\
(A i)\end{array}$ & $\begin{array}{c}\text { Fuzzy Sugeno } \\
(B i)\end{array}$ & \\
\hline 01 September 2018 & 230 & 300 & 230 & 153,75 & 76,25 \\
\hline 02 September 2018 & 280 & 400 & 285 & 285 & 0 \\
\hline 03 September 2018 & 340 & 350 & 340 & 367,50 & $-27,5$ \\
\hline 04 September 2018 & 410 & 500 & 410 & 411,20 & $-1,20$ \\
\hline 05 September 2018 & 350 & 450 & 350 & 278 & 72 \\
\hline 06 September 2018 & 420 & 500 & 420 & 350 & 70 \\
\hline 07 September 2018 & 280 & 400 & 292 & 285,75 & 6,25 \\
\hline 08 September 2018 & 375 & 425 & 410 & 380 & 30 \\
\hline 09 September 2018 & 380 & 400 & 395 & 356 & 39 \\
\hline 10 September 2018 & 280 & 400 & 280 & 286 & -6 \\
\hline 11 September 2018 & 325 & 375 & 350 & 342,50 & 7,50 \\
\hline 12 September 2018 & 390 & 400 & 400 & 389 & 11 \\
\hline 13 September 2018 & 220 & 350 & 220 & 209,75 & 10,25 \\
\hline 14 September 2018 & 420 & 500 & 420 & 422 & -2 \\
\hline 15 September 2018 & 410 & 420 & 410 & 418,50 & $-8,50$ \\
\hline 16 September 2018 & 250 & 300 & 275 & 274 & 1 \\
\hline 17 September 2018 & 360 & 400 & 372 & 378 & -6 \\
\hline 18 September 2018 & 380 & 500 & 394 & 314,75 & 79,25 \\
\hline 19 September 2018 & 290 & 300 & 300 & 275 & 25 \\
\hline 20 September 2018 & 410 & 500 & 410 & 390,75 & 19,25 \\
\hline 21 September 2018 & 440 & 450 & 470 & 561,12 & $-91,12$ \\
\hline 22 September 2018 & 378 & 450 & 378 & 318 & 60 \\
\hline 23 September 2018 & 420 & 500 & 428 & 422 & 6 \\
\hline 24 September 2018 & 220 & 300 & 220 & 238,70 & $-18,70$ \\
\hline 25 September 2018 & 280 & 400 & 280 & 205,20 & 74,8 \\
\hline 26 September 2018 & 320 & 350 & 320 & 336,75 & $-16,75$ \\
\hline 27 September 2018 & 390 & 500 & 398 & 394,25 & 3,75 \\
\hline 28 September 2018 & 270 & 300 & 270 & 287,50 & $-17,50$ \\
\hline 29 September 2018 & 380 & 400 & 380 & 306,90 & 73,1 \\
\hline 30 September 2018 & 420 & 450 & 420 & 350,50 & 69,5 \\
\hline
\end{tabular}

Dari data Tabel 2, dapat dilihat perbandingan hasil produksi dan selisih yang diperoleh antara data jumlah produksi dari Paguyuban dengan Fuzzy Sugeno. Hasil produksi yang diperoleh menggunakan metode fuzzy sugeno dengan data dari Paguyuban, ada beberapa data yang sama, lebih kecil atau lebih besar dari data Paguyuban. Adanya penurunan dan kenaikan dari jumlah produksi menggunakan metode fuzzy sugeno ini disebabkan sistem mengikuti 4 (empat) rule atau aturan yang ditetapkan dari paguyuban. Untuk membuktikan akurasi hasil perhitungan manual dengan sitem dapat digunakan rumus MAPE (Mean Absolute Percentage Error) yaitu [3] : 


$$
\begin{aligned}
\text { MAPE } & =\frac{\sum_{i=1}^{30}\left|\frac{A i-B i}{A i}\right|}{n} \times 100 \% \\
& =\left|\frac{\frac{76,21}{230}+\frac{0}{285}+\frac{27,5}{340}+\ldots+\frac{69,5}{420}}{30}\right| \times 100 \% \\
& =\frac{1,5921}{30} \times 100 \% \\
& =5,3069 \%
\end{aligned}
$$

Diperoleh nilai MAPE sebesar 5,3069\% karena nilai yang diperoleh kurang dari 10\%, berarti metode fuzzy Sugeno dapat diterapkan dengan baik untuk menghitung jumlah produksi tahu di Paguyubaan industri tahu "Waluyo" di Seyegan.

\section{Kesimpulan}

1. Berdasarkan hasil pengujian keakuratan menggunakan metode MAPE (Mean Absolute Percentage Error), diperoleh nilai MAPE sebesar 5,3069\%, dan hal ini menunjukkan tingkat kesalahan dibawah $10 \%$ termasuk dalam kategori baik atau cocok.

2. Metode fuzzy Sugeno dapat diterapkan dalam penentuan jumlah produksi tahu di Paguyuban industri tahu "Waluyo" di Seyegan dengan variabel permintaan, persediaan dan produksi.

3. Pengunaan aturan 4 (empat) rule yang ditetapkan oleh Paguyuban industri tahu "Waluyo" cocok untuk metode fuzzy sugeno ini, tetapi aturan rule tersebut belum tentu cocok untuk industri tahu ditempat lain.

\section{Saran}

Berdasarkan hasil penelitian dapat diberikan saran untuk pengembangan aplikasi ini selanjutnya, yaitu:

1. Merancang aplikasi untuk menentukan jumlah produksi menggunakan fungsi keanggotaan lainnya, dengan memperhatikan nilai MAPE yang semakin kecil.

2. Aplikasi ini dapat dikembangkan berbasis web atau android sehingga dapat digunakan pada industri tahu yang lain.

\section{Ucapan Terima Kasih}

Ucapan terima kasih dihaturkan kepada Institusi Sekolah Tinggi Teknologi Adisutjipto yang sudah mendanai Penelitian Internal ini.

\section{Daftar Pustaka}

[1] Tandian, F. R. (2013). Pengelolaan dan Pengembangan Usaha Produksi Tahu pada Perusahaan Keluarga Ud. pabrik Tahu Saudara di Surabaya. Agora, 1(2), 911-916.

[2] Meysiana, Yoga Rike. Strategi Pengembangan Industri Kecil Tahu Di Kecamatan Sragen Kabupaten Sragen. Diss. Universitas Sebelas Maret, 2010.

[3] Agustin, Ami Hilda, G. K. Gandhiadi, and Tjokorda Bagus Oka. "Penerapan Metode Fuzzy Sugeno untuk Menentukan Harga Jual Sepeda Motor Bekas." E-Jurnal Matematika 5.4: 176-182. 
[4] Bahroini, A., Farmadi, A., \& Nugroho, R. A. (2016). Prediksi Permintaan Produk Mie Instan Dengan Metode Fuzzy Takagi-Sugeno. KLIK\&58; Kumpulan jurnaL Ilmu Komputer, 3(2), 220-230.

[5] Kusumadewi, S. dan Purnomo, H. 2010, Aplikasi Logika Fuzzy Untuk Pendukung Keputusan, Graha Ilmu, Yogyakarta.

[6] Turban E., Aronson J.E., dkk, 2003, Decision Support Systems and Intelligent Systems Sistem FuzzyPendukung Keputusan dan Sistem Cerdas, Andi Offset, Yogyakarta.

[7] Wulandari, F. T. (2013, December). Implementasi Fuzzy Topsis dalam Perencanaan Strategi Bisnis. In Conference SENATIK STT Adisutjipto Yogyakarta (Vol. 1, p. 132).

[8] Kusumaningrum, A. (2013, December). Penerapan Simple Additive Weighting and Location Quotient untuk Menentukan Lokasi Penyebaran Ternak (Studi Kasus: Kabupaten Brebes). In Conference SENATIK STT Adisutjipto Yogyakarta (Vol. 1, p. 108).

[9] Hadiyanti, W. A., Honggowibowo, A. S., \& Suhayati, M. (2013). Analisis Perbandingan Metode Fuzzy Inferensi Sistem Tsukamoto dan Mamdani dalam Penentuan Estimasi Jumlah Produksi Gula. Compiler, 2(1).

[10] Omara, S., \& Honggowibowo, A. S. (2012). Perbandingan Metode Fuzzy Tsukamoto dan Mamdani untuk Merekomendasi Nilai Simpanan Tabungan Berdasarkan Saldo Rata-rata Harian pada Koperasi Jasa Keuangan Syariah (Studi Kasus di Bmt Bina Ihsanul Fikri). Compiler, 1(1).

[11] Indrianingsih, Y. (2016). Perancangan Sistem Pendukung Keputusan dalam Penentuan Jenis Tanaman Palawija Berdasar Kandungan Zat Lahan Guna Meningkatkan Produktivitas Lahan (Studi Kasus di Kabupaten Gunungkidul). Angkasa: Jurnal Ilmiah Bidang Teknologi, 8(1), 127-136.

[12] Honggowibowo, A. S. (2015). Sistem Pendukung Keputusan Penerimaan Calon Mahasiswa Baru Jalur Prestasi di Sekolah Tinggi Teknologi Adisutjipto Menggunakan Simple Multi Attributerating Technique. Angkasa: Jurnal Ilmiah Bidang Teknologi, 7(2), 31-38.

[13] Agustian, H., Honggowibowo, A. S., \& Indrianingsih, Y. (2012). Sistem Pendukung Keputusanpemilihan Guru Teladan dengan Simple Additive Weighting Method (Saw) (Studi Kasus di SMA Angkasa Yogyakarta). Compiler, 1(1). 